\title{
STUDY OF STRUVITE PRECIPITATION IN ANAEROBIC DIGESTERS
}

\author{
C. Maqueda ${ }^{1}$, J. L. Pérez Rodríguez ${ }^{2}$ and J. Lebrato ${ }^{2}$ \\ 'Instituto de Recursos Naturales y Agrobiologia, CSIC Apartado 1052, 41080 Sevilla and ${ }^{2}$ Instituto de \\ Ciencia de Materiales de Sevilla, (Centro Mixto, CSIC-Universidad de Sevilla), Apartado 1.115, \\ 41080 Sevilla, Spain
}

(First received April 1992; accepted in revised form May 1993)

\begin{abstract}
In this paper struvite formation and crystal forms in anaerobic digesters under differing feed types and support media have been studied. Struvite appears when the medium contains magnesium, ammonium and phosphate ions. $\mathrm{NH}_{4}^{+}$can be supplied from protein degradation, phosphate from bacterial exudation and $\mathrm{Mg}^{2+}$ by the supports. The precipitation of struvite has also been checked with real feeding solid wastes plus domestic sewage.
\end{abstract}

Key words - anaerobic digestion, struvite, sepiolite, stevensite, bentonite

\section{INTRODUCTION}

Anaerobic digesters contain ions in solution either from the feeding or as products of the process. Thus, inorganic salts may be precipitated in the digesters when the products of solubility are reached. The orthophosphate ion can form double salts. One of the most characteristic of these is magnesium ammonium phosphate hexahydrate (struvite), whose solubility is greatly affected by the ions present in the medium. The formation of this salt is used in the analysis of phosphorus in the presence of many cations (Van Wazer, 1958).

The kinetics and mechanism of struvite precipitation have been studied by adding a solution of ammonium hydrogen phosphate to a solution of magnesium sulphate and ammonium hydroxide (Gunn and Murthy, 1972). Gunn (1976) also studied the dependence of the induction period upon the mean ionic concentration of $\mathrm{Mg}^{2+}, \mathrm{NH}_{4}^{+}$and $\mathrm{PO}_{4}^{3-}$.

Struvite, $\mathrm{PO}_{4} \mathrm{MgNH}_{4} \cdot 6 \mathrm{H}_{2} \mathrm{O}$, has been found in anaerobic digestion sludges from animal farming liquid wastes (Booram et al., 1975) and in a study on municipal sewage (Borgerding, 1972). An operation scourge at the Hyperion Treatment plant of the city of Los Angeles (U.S.A.) is the precipitation of struvite (Horenstein et al., 1990).

Pérez Rodriguez et al. (1989, 1992) have shown that the magnesium can be supplied by the supports used in the digesters. This cation comes from the exchange positions of the mineral used as support (vermiculite, bentonite and stevensite) and from solubilization of the structure (sepiolite).

Clay minerals used as supports have a great influence on the $\mathrm{pH}$ of the digester medium (Lebrato, 1990). This factor is very important in phosphate precipitation (Schuster and Heine, 1973).
The $\mathrm{PO}_{4}^{3-}$ ion in the precipitation of struvite may come from the anaerobic digestion itself. The supply of $P$ in the anaerobic process was described by Barnard (1976). Fuhs and Chen (1975) have shown that the $\mathbf{P}$ comes from intracellular granules of some polyphosphates of certain types of bacteria.

Polyphosphates act as a reservoir of energy, since they can phosphorylate ADP by the inverse reaction of polyphosphates kinase (Kulaev and Vagabov, 1983). The acetylphosphate formed is transformed into acetylcoenzyme, supplying inorganic phosphate to the cytoplasm, which is exuded from the extracellular medium through the membrane.

The $\mathrm{NH}_{4}^{+}$ion can also be supplied to the medium during anaerobic digestion of nitrogen compounds (such as protein) from the feeding (Lehninger, 1982).

The aim of this paper is to study struvite formation and crystal forms in anaerobic digesters under differing feed types and support media.

\section{EXPERIMENTAL}

\section{Materials}

-Bacterial biomass from an anaerobic reactor that processes piggery wastewater containing the methanogenic flora was used.

- Synthetic culture. The composition of which was sodium acetate, sodium lactate, vitamin, mineral salts, with or without phosphates and proteins according to the experiments carried out.

-Ammonium chloride $(3 \mathrm{~g} / \mathrm{l})$.

-Solid wastes and domestic sewage from the university dining room were used. Solid wastes were crushed and diluted $50 \%$ with domestic sewage.

-Support materials.

- Bentonite from Gador (Spain) supplied by Minas de Gador and magnesium-saturated.

- Stevensite supplied by Tolsa S.A. (Spain).

- Sepiolite (Pansil) from Vallecas (Spain) supplied by Tolsa S.A. 
- Sepiolite and stevensite are magnesium silicates with 10 and 57 mequiv $/ 100 \mathrm{~g}$ of CEC, respectively. Bentonite is an aluminium silicate with 90 mequiv $/ 100 \mathrm{~g}$ of CEC.

The mineral bentonite was saturated in $\mathbf{M g}^{2+}$ by several treatments with $0.1 \mathrm{M}$ solutions of the corresponding chloride.

\section{Methods}

The experiments were carried out in single-load microdigesters designed by Lebrato (1990) which permit working under anaerobiosis and taking samples when required. The microdigesters consisted of a screw-cap bottle with an exit valve for gases. Other experiments were carried out in reactors of 1 litre capacity filled with $10 \mathrm{~cm}^{3}$ of the materials described, and provided with magnetic stirrers. One blank support-free reactor was prepared for comparison.

The reactors were kept at a constant temperature of $35^{\circ} \mathrm{C}$

Samples of the precipitates from the digesters were taken at 30,60 and 90 days after starting the anaerobic process. Prior experiments at intermediate times had been carried out, but the chosen times showed the differences in the experimental data better. The samples were studied using the following methods:

(1) X-Ray diffraction (XRD) in a Siemens diffractometer, model Kristaloflex D-500, using $\mathrm{Ni}$ filtered $\mathrm{CuK} \alpha$ radiation. The goniometer speed was $1 \% \mathrm{~min}$ and the chart speed $1 \mathrm{~cm} / \mathrm{min}$. The $\mathrm{kV}$ and $\mathrm{mA}$ used were 36 and 26 , respectively. The specimens for X-ray work were prepared as follows: samples taken from the digester were deposited on a glass slide and dried at room temperature.

(2) Scanning electron microscopy (SEM) was performed in an ISSI apparatus, model SS40, and the dispersion energy of X-rays (EDX) was measured by a Kevex analyser, model 8000 . Before examination, the samples were made conductive by coating with gold.
The struvite crystal sizes were a mean value obtained from different photographs of various fields observed in the SEM. The smallest crystals were ignored, since they were from late growth or other factors such as poor nucleation, co-precipi tates, etc. Moreover, such small crystals are impossible to measure in the SEM photographs.

\section{RESULTS AND DISCUSSION}

Precipitates appeared in microdigesters inoculated with bacterial mass supplied with clay minerals as supports (bentonite-Mg, stevensite and sepiolite) both when the synthetic feed contained phosphate and $\mathrm{NH}_{4} \mathrm{Cl}$, and when it contained phosphate and proteins without added $\mathrm{NH}_{4}^{+}$

The X-ray powder patterns of the precipitates showed the series of diffractions corresponding to struvite $(5.90,5.60,5.37,4.25,4.13,2.69$. A, etc.). The crystallographic parameters determined by $\mathrm{X}$-ray diffraction were the following: $a_{0}=6.9458 \pm 0.0033$, $b_{0}=11.2097 \pm 0.0047, \quad c_{0}=6.1344 \pm 0.002$. These parameters coincide with those of the orthorhombic cell unit of struvite.

SEM study showed crystals with a morphology typical of these phosphates (Figs 1 and 2). Their analysis by EDX showed that they were composed of phosphorus and magnesium (Fig. 3), confirming the presence of struvite.

In the digesters fed with proteins, no ammonium was supplied by the feed or any other source. Therefore the $\mathrm{NH}_{4}^{+}$ions present in the inoculated system must have come from degradation of the proteins of the feed during the anaerobic digestion. $\mathrm{The}^{\mathbf{M g}^{2+}}$ must be contributed by the supports, as in no case was magnesium supplied in the feed or from another source.

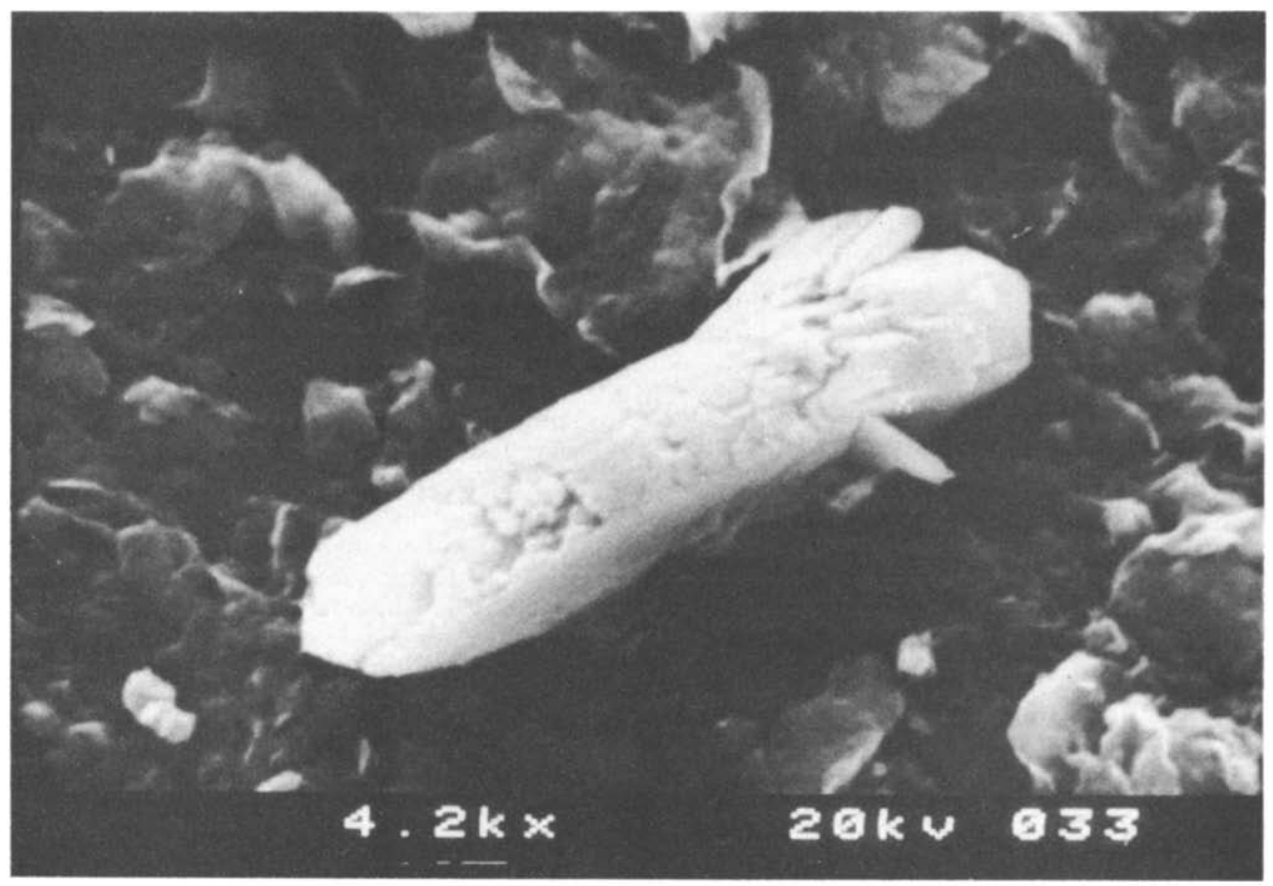

Fig. 1. Scanning electron micrograph of struvite from a digester with bentonite as support. 


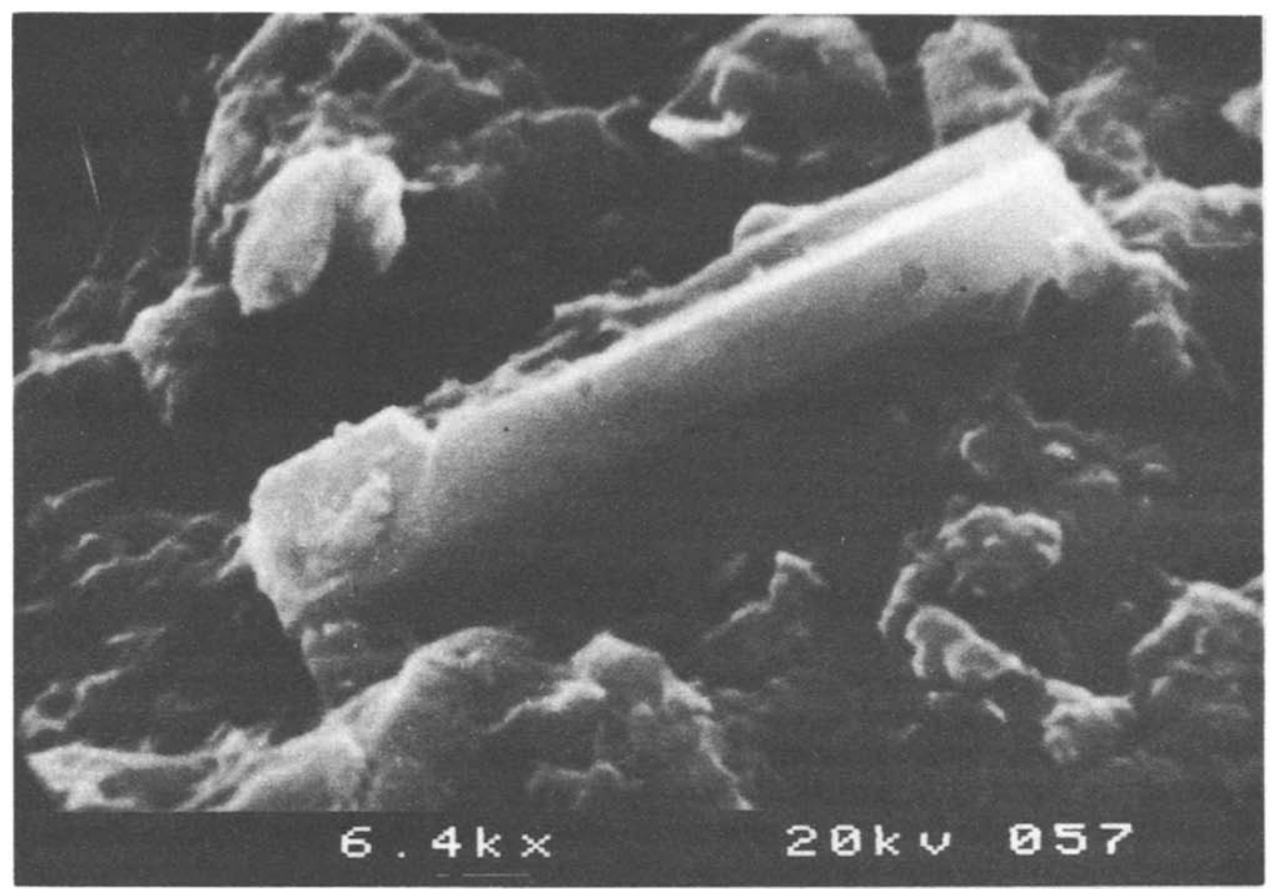

Fig. 2. Scanning electron micrograph of struvite from a digester with stevensite as support.

It is remarkable that in systems with $\mathrm{NH}_{4}^{+}$added to the solution as $\mathrm{NH}_{4} \mathrm{Cl}(3 \mathrm{~g} / \mathrm{l})$, crystal growth was quicker than when proteins were present (the crystal size of the early precipitates was greater in the former case than in the latter). When $\mathrm{NH}_{4}^{+}$was added to the medium, the factor determining growth of magnesium ammonium phosphate was the cessation of $\mathrm{Mg}^{2+}$ from the support to the solution. When $\mathrm{NH}_{4} \mathrm{Cl}$ was not supplied to the medium, the reaction rate was determined by the supply of $\mathrm{NH}_{4}^{+}$from protein degradation and cessation of $\mathrm{Mg}^{2+}$ by the support. Given that the supply of $\mathrm{Mg}^{2+}$ is more rapid than that of $\mathrm{NH}_{4}^{+}$, when the magnesium is in the form of exchange ion (as is the case of bentonite- $\mathrm{Mg}$ and stevensite), the growth of phosphate is determined by the supply of $\mathrm{NH}_{4}^{+}$from protein degradation. An

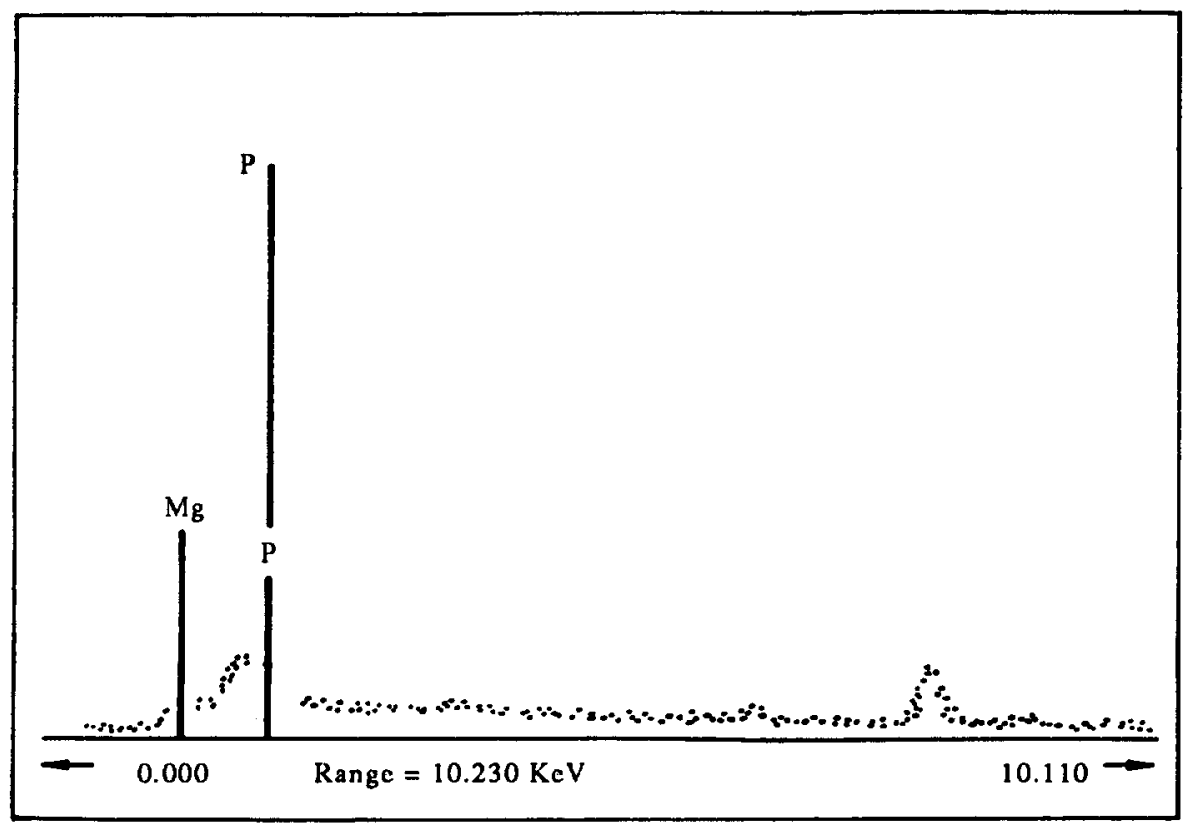

Fig. 3. Chemical analysis by EDX corresponding to the crystals from Figs 1 and 2. 
Table 1. Dimension of the struvite crystals appearing in the different digesters as a function of the time. (a) With NH, $C$ and (b) with preting $W=$ widh $L$ - lenth; both in $\mu \mathrm{m}$

\begin{tabular}{|c|c|c|c|c|c|c|}
\hline & \multicolumn{2}{|c|}{30 days } & \multicolumn{2}{|c|}{60 days } & \multicolumn{2}{|c|}{90 days } \\
\hline & $\mathbf{a}$ & $\mathbf{b}$ & $\mathbf{a}$ & b & $\mathbf{a}$ & b \\
\hline Bentonite- $\mathbf{M g}$ & $\begin{array}{ll}W & 12 \\
L & 30\end{array}$ & $\begin{array}{lc}W & 5 \\
L & 25.5\end{array}$ & $\begin{array}{ll}W & 10 \\
L & 30\end{array}$ & $\begin{array}{lc}W & 6 \\
L & 35.5\end{array}$ & $\begin{array}{ll}W & 10 \\
L & 38\end{array}$ & 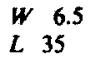 \\
\hline Stevensite & $\begin{array}{ll}W & 12.5 \\
L & 30\end{array}$ & $\begin{array}{lr}W & 7.5 \\
L & 30.5\end{array}$ & $\begin{array}{ll}W & 12 \\
L & 28.5\end{array}$ & $\begin{array}{ll}W & 10 \\
L & 30.5\end{array}$ & $\begin{array}{ll}W & 15 \\
L & 32\end{array}$ & $\begin{array}{ll}W & 12 \\
L & 32\end{array}$ \\
\hline Sepiolite & $\begin{array}{c}\text { Does not } \\
\text { appear }\end{array}$ & $\begin{array}{l}\text { Does not } \\
\text { appear }\end{array}$ & $\begin{array}{l}W 10.5 \\
L 30\end{array}$ & $\begin{array}{ll}W & 10 \\
L & 27\end{array}$ & $\begin{array}{ll}W & 12 \\
L & 36\end{array}$ & $\begin{array}{ll}W & 11 \\
L & 35\end{array}$ \\
\hline
\end{tabular}

example is the case of the digester with bentonite- $\mathrm{Mg}$ as support. After 30 days the surface area of the crystal formed when $\mathrm{NH}_{4} \mathrm{Cl}$ was present in the medium was $360 \mu \mathrm{m}^{2}$ against $127 \mu \mathrm{m}^{2}$ when protein and not $\mathrm{NH}_{4}^{+}$was added (Table 1). In the case of stevensite the areas were $375 \mu \mathrm{m}^{2}$ and $258 \mu \mathrm{m}^{2}$ depending on the presence or not respectively of $\mathrm{NH}_{4} \mathrm{Cl}$ in the medium. When $\mathrm{NH}_{4}^{+}$(as $\mathrm{NH}_{4} \mathrm{Cl}$ ) was not present, the crystal size was much greater with stevensite than when using bentonite- $\mathrm{Mg}$. This may be due to the fact that the supports affect the anaerobic digestion, and the contribution of stevensite is greater than that of bentonite. However, together with the mineralogical composition of the support there are other factors, such as the effect of the pH of the medium, impurities of the material, specific surface of the support etc., that must be considered in the anaerobic digestion.

The foregoing indicates that in the case of bentonite- $\mathrm{Mg}$, the magnesium cation is in solution from the start. It is given up quickly due to the great and easy exchange capacity of this mineral. Phosphate is also present from the start because it is added in the feeding. Thus with added $\mathrm{NH}_{4} \mathrm{Cl}$, struvite appears from the start, as all the ions are in solution, and precipitation is very rapid, in agreement with the kinetic studies of Gunn and Murthy (1972). For this

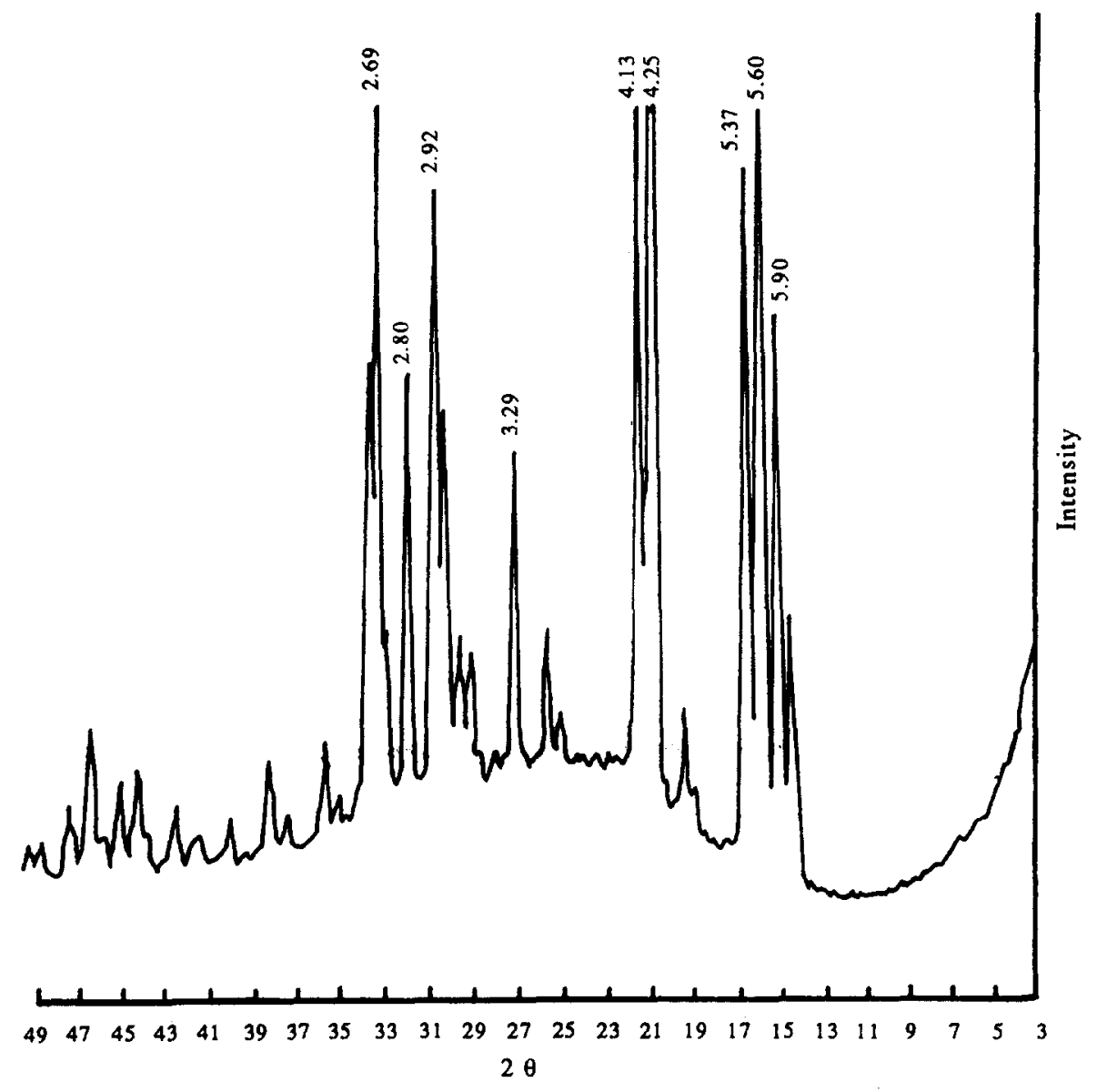

Fig. 4. X-Ray diffraction pattern of separated crystals of struvite. 


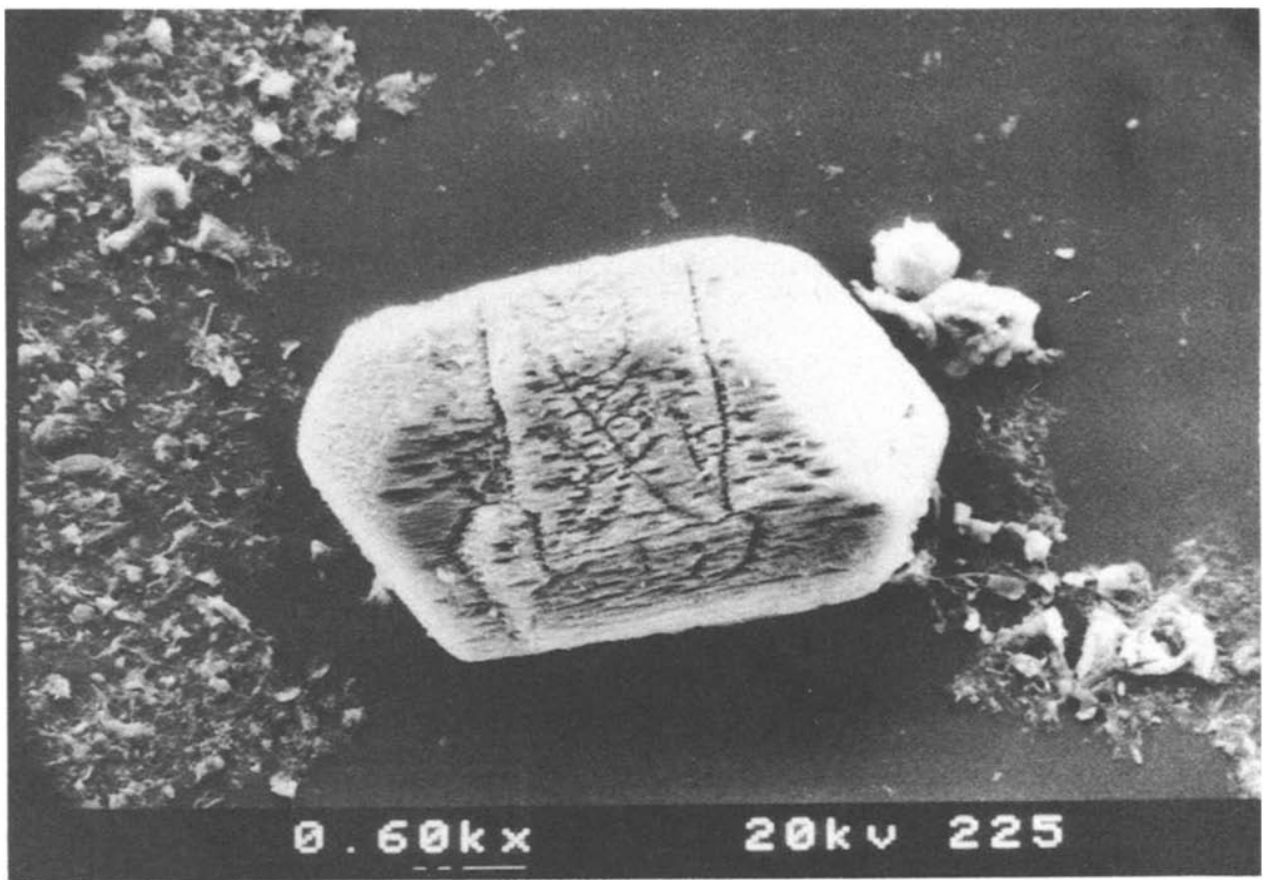

Fig. 5. Scanning electron micrograph of struvite from continuous digesters with bentonite-Mg as support.

reason, crystal growth soon stops, and the size is the same at 60 and 90 days.

Although struvite precipitation was observed earlier than indicated, experiments carried out at intermediate times established these as showing the differences better.

When there were proteins but not $\mathrm{NH}_{4}^{+}$in the medium, the crystal size changed with time.

Other digesters were prepared with all the supports studied in this paper, and supplied with synthetic feed containing phosphate and proteins. These digesters were not inoculated with bacteria. In these cases there was no precipitation, because the medium contained no $\mathrm{NH}_{4}^{+}$, neither from the feed nor from protein degradation.

All the above-described experiments were carried out in batch microdigesters. In a second stage, the conditions of struvite precipitation were studied in continuous digesters with daily feeding, being bigger that the development of methanogenic biomass. These digesters were fed with synthetic feeding without phosphates and with mineral salts and proteins. Some crystals were observed whose X-ray diagram indicated struvite (Fig. 4). This was confirmed by EDX. Figure 5 shows crystals of this salt. Struvite was precipitated in these digesters as a result of daily feeding, with consequent greater bacterial growth and exudation of $\mathrm{P}$ as $\mathrm{PO}_{4}{ }^{3-}$ from cell metabolism. The appearance of these phosphates with the bacterial exudation of $P$ is in agreement with the data of Somiya et al. (1987) and Comeau et al. (1987).
The size of the crystals in the continuous digesters is greater than in batch microdigesters, which are fed only once.

Finally, when the digesters were fed with waste and domestic sewage instead of synthetic feeding, struvite appeared in all cases.

\section{REFERENCES}

Barnard J. L. (1976) A review of biological phosphorus removal in the activated sludge process. Wat. SA 2, 136. Booram C. V., Smith R. J. and Hazen T. E. (1975) Crystalline phosphate precipitation from anaerobic animal waste treatment lagoon liquors. Am. Soc. civ. Engrs Trans. 18, 340-343.

Borgerding J. (1972) Phosphate deposits in digestion systems. J. Wat. Pollut. Control Fed. 44, 813-819.

Comeau Y., Rabionwitz B., Hall K. J. and Oldham W. K. (1987) Phosphate release and uptake in enhanced biological phosphorus removal from wastewater. $J$. Wat. Pollut. Control Fed. 59, 707-715.

Fuhs G. W. and Chen M. (1975) Microbiological basis of phosphates removal in the activated sludge process for the treatment of wastewater. Microb. Ecol. 2, 119.

Gunn D. J. (1976) Mechanism for the formation and growth of ionic precipitates from aqueous solution. Faraday Disc. Chem. Soc. 61, 133-140.

Gunn D. J. and Murthy M. S. (1972) Kinetics and mechanisms of precipitation. Chem. Engng Sci. 27, 1293-1313.

Horenstein B. K., Hernandez G. L., Rasberry G. and Grosse J. (1990) Successful dewatering experience at Hyperion wastewater treatment plant. Wat. Sci. Technol. 22, $183-191$.

Kulaev I. S. and Vagabov V. M. (1983) Polyphosphate metabolism in microorganism. Adv. Microb. Physiol. 24, 83-171. 
Lebrato J. (1990) Obtaining biogas from organic urban wastes. Experiment in fluidized bed. Doctoral thesis, University of Seville, Spain (in Spanish).

Lehninger A. L. (1982) Principles of Biochemistry. Worth, New York

Pérez Rodriguez J. L., Carretero M. I. and Maqueda C. (1989) Behaviour of sepiolite, vermiculite and montmorillonite as support in anaerobic digesters. Appl. Clay Sci. 4, 69-82.

Pérez Rodríguez J. L., Maqueda C., Lebrato J. and Carretero M. I. (1992) Influence of clay minerals used as supports in anaerobic digesters, in the precipitation of struvite. Wat. Res. 26, 497-506.

Schuster G. and Heine A. (1973) Das Verfahren der chemischen Fallung zur Elimination der Phosphorverbindungen aus häulichem Abwaser, 38. Berlin.

Somiya I., Tsuno H. and Matsumoto M. (1988) Phosphorus release-storage resction and organic behaviour in biological phosphorus removal. Wat. Res. 22 , 49-58.

Van Wazer J. R. (1958) Phosphorus and Its Compounds. Volume I: Chemistry. Interscience, New York. 